
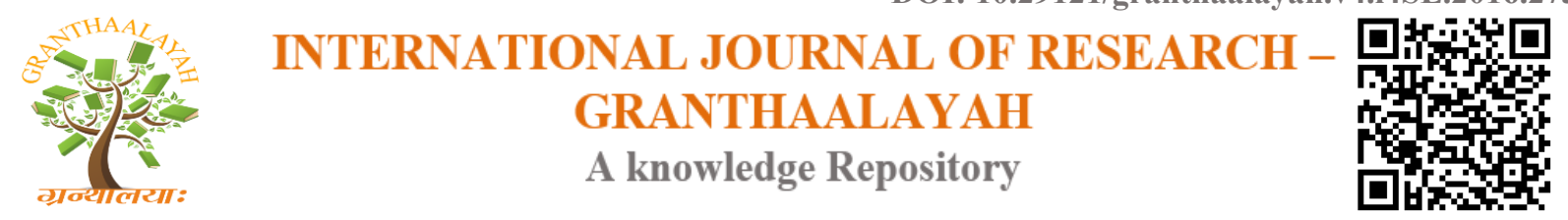

Management

\title{
A STUDY ON CONSUMER BEHAVIOUR TOWARDS POTHYS TEXTILE IN TIRUNEL VELI DISTRICT
}

\author{
Dr. A.Hamil ${ }^{* 1}$, M.Kothai Natchiar ${ }^{2}$ \\ ${ }^{* 1}$ Associate Professor of Commerce and Dean of Arts, Sadakathullah Appa College, Tirunelveli, \\ INDIA \\ ${ }^{2}$ M.Phil Research Scholar in Commerce, Sadakathullah Appa College, Tirunelveli, INDIA
}

\begin{abstract}
Now a days the consumer buying behaviour is changing day by day. The ultimate decision of whether (or) not to purchase a product (or) service and from whom to buy has always been vested in the hands of the final consumers. In this article I discussed about the various sections and types of sarees sold in Pothys textile and Guinness record saree and also in this study provide on consumer behavior towards Pothys textile.
\end{abstract}

Keywords:

Consumer, Buying Behaviour, Product, \& Pothys.

Cite This Article: Dr. A.Hamil, and M.Kothai Natchiar, "A STUDY ON CONSUMER BEHAVIOUR TOWARDS POTHYS TEXTILE IN TIRUNELVELI DISTRICT” International Journal of Research - Granthaalayah, Vol. 4, No. 4: SE (2016): 21-28.

\section{INTRODUCTION}

Right from the time there has been exchange of goods and services between the buyer and the seller. The ultimate success of all the economic activities has primarily depends on the producer manufacturing and selling goods and services desired by the target consumers. There is always as to attempt on the part of the marketer to understand and study consumer behavior. This can be referred to as an attempt to understand and predict human actions in the buying role. The study of the consumer behavior is comparatively a new research field. Consumer behavioural studies held all those bodies of knowledge concerned with human behaviour Economics, Psychology, Sociology cultural anthropology and Socio-Psychology.

In the present study an attempt has been made to understand various dimensions of consumer behaviour understanding the buyer behaviour will provide in right to the marketing manager on how to go about planning and implementing their various marketing programmes. India has a rich and varied Heritage. It will be interesting to understand the nature and characteristics of Indian consumer, whose buying decisions will be based on the influence of values, beliefs, customs and practices and behaviour of the particular society of which they are a part. 


\section{POTHYS TEXTILE}

\section{A. TEXTILE - INTRODUCTION}

A Textile is a flexible material comprised of a network of natural (or) artificial fibers often referred to as thread (or) yarn. Yarn is produced by spinning raw wood fibers, Cotton (or) other material on a spinning wheel to produce long stands known as yarn. Textile is framed by weaving, knitting, crocheting, knotting (or) processing fibers together.

\section{B. TERMINOLOY}

The words fabric and cloth are commonly used textile assembly trades (such as tailoring and dress making) as Synonyms for textile. However there are subtle differences in these terms. Textile refers to any material made of interlacing fibers. Textile has an assortment of uses, the most common of which are for clothing and containers such as bags and baskets. The basic needs of human being are food, clothing \& shelter. In these basic needs we are going to see about clothing.

\section{FASHION AND TEXTILE DESIGN}

Fashion designers commonly rely on textile design to set their fashion collection a port from others.

\section{VARIOUS SECTIONS IN POTHYS}

1. Pothys - Silk

2. Textiles - Shirting \& Suiting

3. Fabrics - Sarees, Voil Sarees

4. Moopanars - Blouse material, Gada Pothys

5. Garments - Children's, Gents, Ladies.

\section{E. TYPES OF SAREES SOLD IN POTHYS}

1. Samudrika Pattu.

2. Parmpara Pattu.

3. Subamangala Silks

4. Vastrakala Pattu.

5. Kancheepuram Silks.

6. Party wear Sarees.

7. Printed Silks.

8. Handloom Silks.

9. Silk Cotton.

10. Embroidery Sarees.

11. Kutty Sarees. 


\section{F. GUINNESS RECORD SAREE}

The motits that adorn the saree were first created on canvas before being woven in pure gold zari on the saree. The images recreated on this saree historically trace India's progress beginning with glimpses from the Mohan jadaro Harappa Civilization, Rama era, Krishna era, Budha Mahavera, Maurya, Chera, Pandiyas, Rajputs, Moghulas and culminating with the nation's freedom struggle. A part from this it also features images of India's map, the Globe and Movements of national importance.The cultural and social diversity of India has also found a place on this silken canvas with images depicting folk dances, festivals and cultural attire. Images of some of our great peoples like Mahatma Gandhi, Thiruvalluvar and Swami Vivekananda.

Hon'ble Thiru. Surjeet singh Barnala, Governor of Tamil Nadu was gracious enough to formally launch this saree at a function in Raj Bhavan, Chennai. Thegovernor praised the efforts that have gone into creating the saree and launched the distinction achieved by Pothys.

The record saree was unveiled for public viewing by Dr. Nally Kuppusamy Chettiar in the presence of Mrs. Y.G. Parthasarathy - theveducationist, Mrs. Padma Subramanian - a well known Bharathanatiyam dancer, Mrs. Sudha Ragunathan the popular Carnatic singer. Dr. Nalli Kuppusamy Hettiar also honoured the weavers and the articians involved in the project.

\section{CONSUMER BEHAVIOUR}

\section{A. MEANING OF CONSUMER BEHAVIOUR}

Consumer behaviour is the study of when, why, where, what and how people do (or) do not buy products. It blends elements from Psychology, Sociology, Social Psychology, anthropology and economics. It attempts to understand the buyer decision making process, both individually and in groups. It studies characteristics of individual consumer such as demographics and behavioural variables in an attempt to understand people's wants. It also tries to assess influences on the consumer from groups such as family, friends, reference groups, and society in general.

\section{B. DEFINITION OF CONSUMER BEHAVIOUR}

Belch \& Belch defines consumer behaviour as "The process and activities people engage in when searching for selecting, purchasing, using evaluating, and disporing of products and services so as to satisfy their needs and desires".

\section{STATEMENT OF THE PROBLEM}

A study on consumer preference towards Pothys in Tirunelveli District was selected as problem area. The survey was conducted among the consumers of Tirunelveli City.

\section{OBJECTIVES OF THE STUDY}

1. To assess the consumer attitude towards price level of Pothys.

2. To know the reason for purchasing in Pothys products. 
3. To study about the opinion of consumers about quality of textile sold in Pothys.

4. To know the consumers opinion about the customer service in Pothys.

\section{E. SCOPE OF THE STUDY}

Present study was conducted among different groups of consumers according to the age group, Occupational, status and income.

\section{F. METHODOLOGY}

The primary and secondary data are collected for the purpose of the study. Primary data are those which are collected for the first time and they are original in character. Secondary data are those data which are already collected by same agency for some other purpose.

\section{G. SAMPLE SIZE}

For this study we have collected 50 sample respondents from the people who came as customers to Pothys Textile at Tirunelveli Town, by supplying questionnaires and by personal interview method.

\section{H. HYPOTHESIS}

Ho: There is no relationship between Age and Customer service level.

\section{RESULTS AND DISCUSSION}

Table showing age group respondents

Table 1:

\begin{tabular}{|l|l|l|l|}
\hline S. No & Age & $\begin{array}{l}\text { No of } \\
\text { respondent } \\
\text { s }\end{array}$ & Percentage \\
\hline 1. & Below 20years & 5 & 10 \\
\hline 2. & 20-30 years & 15 & 30 \\
\hline 3. & 30-40 years & 10 & 20 \\
\hline 4. & 40-50 years & 8 & 16 \\
\hline 5. & Above 50years & 12 & 24 \\
\hline & Total & $\mathbf{5 0}$ & $\mathbf{1 0 0}$ \\
\hline
\end{tabular}

From the above table we come to know that many respondents are belonging in the age group of $20-30$ years this will be explanted the following multiple bar diagram. 


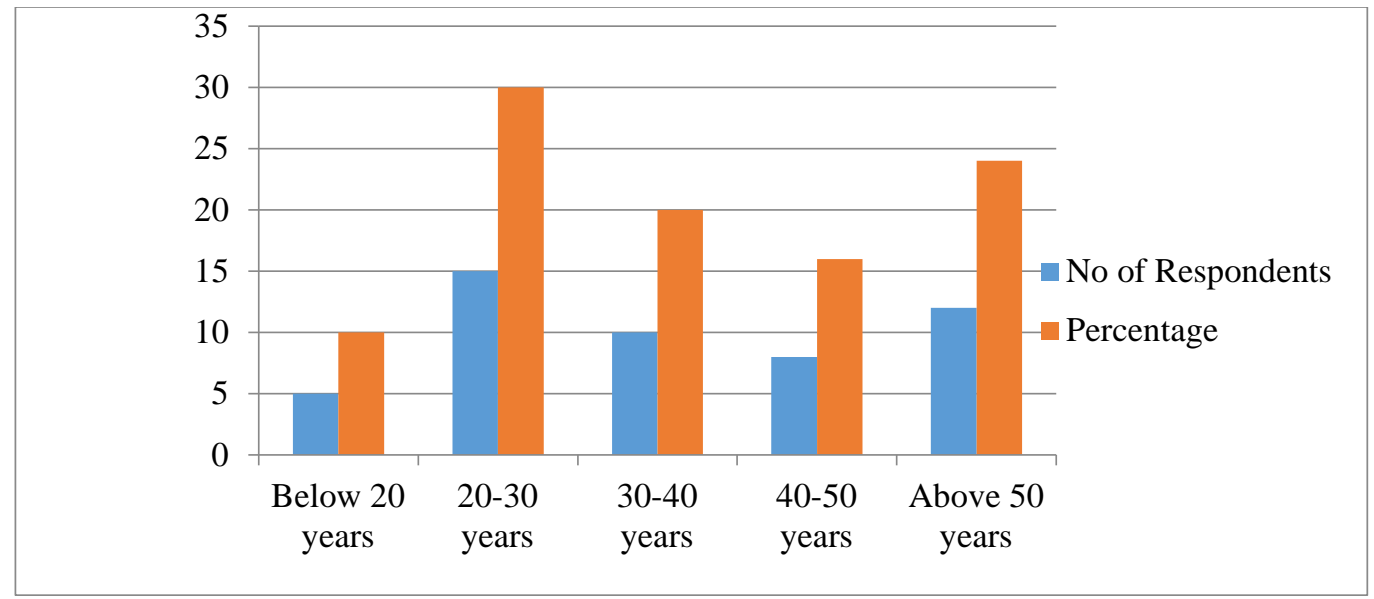

2. Table showing income wise respondents

Table 2:

\begin{tabular}{|c|c|c|c|}
\hline S. No & $\begin{array}{l}\text { Income per Month } \\
\text { Rs. }\end{array}$ & \begin{tabular}{|l|} 
No \\
Respondents
\end{tabular} & Percentage \\
\hline 1. & Below 5000 & 9 & 18 \\
\hline 2. & $5000-10000$ & 10 & 20 \\
\hline 3. & 1000020000 & 16 & 32 \\
\hline 4. & Above 20000 & 15 & 30 \\
\hline & Total & 50 & 100 \\
\hline
\end{tabular}

From the above table it is clear that $16(32 \%)$ respondents are belonging to the income ranging from Rs. $10000-20000 \&$ they form major part this will be explained in the following simple pie diagram

No of Respondents

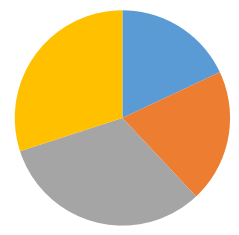

$$
\begin{aligned}
& - \text { Below } 5000 \\
& -5000-10000 \\
& -10000-20000 \\
& \text { Above } 20000
\end{aligned}
$$

3. Table showing the Different level of Age group respondents and Customer service in Pothys textile

Table 3:

\begin{tabular}{|l|l|l|l|l|l|l|}
\hline Age & \multicolumn{4}{|l|}{ Customer service } & \multirow{2}{*}{ Total } \\
\cline { 2 - 5 } & Excellent & Good & Satisfactory & Poor & Very Poor & \\
\hline
\end{tabular}




\begin{tabular}{|l|l|l|l|l|l|l|}
\hline Below 20 & 2 & 1 & 3 & 1 & 0 & 7 \\
\hline $\mathbf{2 0}-\mathbf{3 0}$ & 3 & 2 & 2 & 4 & 0 & 11 \\
\hline $\mathbf{3 0}-\mathbf{4 0}$ & 4 & 3 & 2 & 3 & 1 & 13 \\
\hline $\mathbf{4 0}-\mathbf{5 0}$ & 2 & 1 & 3 & 4 & 1 & 11 \\
\hline $\begin{array}{l}\text { Above } \\
\mathbf{5 0}\end{array}$ & 1 & 1 & 1 & 1 & 4 & 8 \\
\hline Total & $\mathbf{1 2}$ & $\mathbf{8}$ & $\mathbf{1 1}$ & $\mathbf{1 3}$ & $\mathbf{6}$ & $\mathbf{5 0}$ \\
\hline
\end{tabular}

Ho: There is no relationship between Age and Customer service.

Let us take the null hypothesis that the Age and Customer service level are independent. The table showing the Expected Frequency

Table 4:

\begin{tabular}{|l|l|l|l|l|l|l|}
\hline Below 20 & 1.68 & 1.12 & 1.54 & 1.82 & 0.84 & 7 \\
\hline $\mathbf{2 0}-\mathbf{3 0}$ & 2.64 & 1.76 & 2.42 & 2.86 & 1.32 & 11 \\
\hline $\mathbf{3 0}-\mathbf{4 0}$ & 3.12 & 2.08 & 2.86 & 3.38 & 1.56 & 13 \\
\hline $\mathbf{4 0}-\mathbf{5 0}$ & 2.64 & 1.76 & 2.42 & 2.86 & 1.32 & 11 \\
\hline Above 50 & 1.92 & 1.28 & 1.76 & 2.08 & 0.96 & 8 \\
\hline Total & $\mathbf{1 2}$ & $\mathbf{8}$ & $\mathbf{1 1}$ & $\mathbf{1 3}$ & $\mathbf{6}$ & $\mathbf{5 0}$ \\
\hline
\end{tabular}

\begin{tabular}{|l|l|l|l|}
\hline 0 & $\mathrm{E}$ & $(\mathrm{O}-\mathrm{E}) 2$ & $(\mathrm{O}-\mathrm{E}) 2 / \mathrm{E}$ \\
\hline 2 & 1.68 & 0.102 & 0.06 \\
\hline 3 & 2.64 & 0.129 & 0.04 \\
\hline 4 & 3.12 & 0.774 & 0.24 \\
\hline 2 & 2.64 & 0.409 & 0.15 \\
\hline 1 & 1.92 & 0.846 & 0.44 \\
\hline 1 & 1.12 & 0.014 & 0.11 \\
\hline 2 & 1.76 & 0.057 & 0.23 \\
\hline 3 & 2.08 & 0.846 & 0.91 \\
\hline 1 & 1.76 & 0.577 & 0.75 \\
\hline 1 & 1.28 & 0.078 & 0.27 \\
\hline 3 & 1.54. & 2.131 & 1.38 \\
\hline 2 & 2.42 & 0.176 & 0.41 \\
\hline 2 & 2.86 & 0.739 & 0.85 \\
\hline 3 & 2.42 & 0.336 & 0.57 \\
\hline 1 & 1.76 & 0.577 & 0.32 \\
\hline 1 & 1.82 & 0.672 & 0.81 \\
\hline 4 & 2.86 & 1.299 & 1.13 \\
\hline 3 & 3.38 & 0.144 & 0.37 \\
\hline
\end{tabular}




\begin{tabular}{|l|l|l|l|}
\hline 4 & 2.86 & 1.299 & 1.13 \\
\hline 1 & 2.08 & 1.166 & 1.07 \\
\hline 0 & 0.84 & 0.705 & 0.83 \\
\hline 0 & 1.32 & 1.742 & 1.31 \\
\hline 1 & 1.56 & 0.313 & 0.55 \\
\hline 1 & 1.32 & 0.102 & 0.07 \\
\hline 4 & 0.96 & 9.241 & 9.62 \\
\hline & & Total & $\mathbf{2 3 . 6 2}$ \\
\hline
\end{tabular}

Degrees of freedom $=(\mathrm{r}-1)(\mathrm{c}-1)$

$$
\begin{aligned}
& =(5-1)(5-1) \\
& =4 \times 4 \\
& =16
\end{aligned}
$$

Table value of $16=26.29$

The table value for 16 d.f at $5 \%$ level of significance is 26.29 . The calculated value is less than the table value. The null hypothesis is accepted. Hence the age and customer service are independent.

\section{FINDINGS AND SUGGESTIONS}

\section{A. FINDINGS}

1. It is found that most of the respondents are regular customer of Pothys.

2. It is assessed that youngsters are more interested in buying textile item from Pothys.

3. It is found that income level of respondents were between $10000-20000$ per month.

4. It is assessed that some customers are not regular customer of Pothys because of high price.

5. It is found that quality, varieties and designs and customer services are very excellent in Potyhs.

\section{B. SUGGESTIONS}

1. It is advised that if the prices of the textile are reduced. The sales volume can be further increase.

2. Delay in billing section should be avoided.

3. The quality should be further improved.

4. The salesmen in Pothys should show varieties of material without hesitation.

5. The Pothys can arrange some refreshment to satisfy the customers' needs.

\section{CONCLUSION}

Consumer is a complex entity, so consumer behaviours research studies are gaining importance today. The consumer behaviour process is being studied for various angles, comprising of Psychology, Social Psychology, cultural anthropology and economics.

However, this is going to be continuous process and can only conclude by saying that with most of the firms involved in such intensive probing into the complex consumer behaviour, Probably 
in the days to come, marketing managers may be able to understand the consumer behaviour better than he is today. The history of the Pothys says it has its own Royal customers. Majority of people in Tirunelveli go for Vadaku Radha Vethi for their purchase. The well placed customer service has its own group of people for their purchase in Pothys. The Royal customers are well attached to the Sentimental feel over there.

\section{REFERENCES}

[1] Suja R.Nair A text book as "Consumer Behaviour” Himalaya publishing house

[2] R.S.N. Pillai and Bhagavathi A text book as "Marketing Management"

[3] Golden, S. A. R. (2015). Regional Imbalance affecting quality of e-banking services with special reference to Tuticorin District-An Analysis. International Journal of Research, 2(3), 788-798.

[4] Regi, S. B. \& S, A. R. G. (2014). “A DESCRIPTIVE STUDY ON THE ROLE OF CONSUMER

PSYCHOLOGY AND BEHAVIOUR IN PRODUCT PURCHASING”. Indian Streams Research Journal, 3

[5] www.pothys.com

[6] www.ask.com

[7] www.wikipidia.com 